\title{
Fishes: The Forgotten Sentient Beings
}

\author{
Helena Bauer \\ MA Animal Law and Society (UAB) \\ Project Assistant, Animals' Angels e.V.
}

Received: March 2019

Accepted: March 2019

Recommended citation. BAUER H., Fishes - The Forgotten Sentient Beings, dA. Derecho Animal (Forum of Animal Law Studies) 10/2 (2019) - DOI https://doi.org/10.5565/rev/da.427

\begin{abstract}
Fish - these four letters stand for an enormous number of trillions of animals but still up to the present day we only know little about their inner life. There have been numerous studies showing impressively that they indeed feel pain. Even though they lack a human-like neocortex, apparently other parts of the fish brain seem to be responsible for processing emotions and consciousness. Observations from nature strongly support the remarkable capacity of fishes to live a conscious life: they have an excellent memory and use land marks for orientation, recognize the different individuals in their shoal and remember their hierarchical status in the group. They cooperate between species and even invent interspecific sign language. In conclusion, there is clear evidence that fishes are conscious, sentient beings - and indeed since 2009 they are recognized as such by the EU in article 13 TFEU. However, under welfare aspects of secondary EU legislation, the fishes are either only included on a very basic general level or not considered at all. Especially considering the numbers of fish individuals and the methods used in fisheries and aquaculture, it is high time to overcome this erroneous view and to finally grant them the protection they deserve as 'sentient beings' - on the legislative level, but also in fisheries and aquaculture practices, policies, and not least in our daily behaviour.
\end{abstract}

Keywords: fishes; sentience; fisheries; aquaculture; article 13 TFEU.

Resumen - Peces: los seres sintientes olvidados

Peces: estas cinco letras representan una enorme cantidad de trillones de animales pero hasta el día de hoy poco sabemos sobre su vida interior. Ha habido numerosos estudios que muestran de manera impresionante que realmente sienten dolor. A pesar de que carecen de un neocórtex similar al humano, aparentemente otras partes del cerebro de los peces parecen ser responsables del procesamiento de las emociones y la conciencia. Las observaciones de la naturaleza apoyan firmemente la notable capacidad de los peces para llevar a cabo una vida consciente: tienen una excelente memoria y utilizan las marcas de tierra para la orientación, reconocen a los diferentes individuos en su banco y también recuerdan su estado jerárquico en el grupo. Cooperan entre especies e incluso inventan el lenguaje de signos interespecífico. En conclusión, existe una clara evidencia de que los peces son seres conscientes y sintientes y, de hecho, desde 2009 están reconocidos como tales por la UE en el artículo 13 del TFUE. Sin embargo, bajo los aspectos de bienestar de la legislación secundaria de la UE, los peces se incluyen solo en un nivel general muy básico o no se consideran en absoluto. Especialmente teniendo en cuenta el número de individuos de peces y los métodos utilizados en la pesca y la acuicultura, es hora de superar este punto de vista erróneo y otorgarles finalmente la protección que merecen como "seres sintientes" a nivel legislativo pero también en las prácticas y políticas de la pesca y la acuicultura y, no menos importante, en nuestro comportamiento diario.

Palabras clave: peces; sentiencia; pesca; acuicultura; articulo 13 TFUE. 
"Are you ready for one of the greatest adventures?" - one may wonder to read this advertisement from a Spanish fish producing company. The Group Balfegó, which is farming blue fin tuna in aquaculture near Tarragona, offers 'Tuna Tours' in which tourists and interested people can "dive and swim [inside the cages] alongside the largest tuna in the world and experience moments of excitement with all 5 senses". 2 Depending on the package booked, the people can 'relish' tuna in the form of a meal on board the catamaran, after having had their underwater adventure with the live animals. One may also wonder to read about the current EU Commission's Inseparable initiative, which is promoting sustainably EU-farmed 'seafood' by asking the EU Citizens "to help ensure future generations have the same love story we have with our fish today". ${ }^{3}$ And one may wonder about the exhibition in 2000 in which the artist Marco Evaristti invited visitors to switch on food blenders with live goldfishes inside. ${ }^{4}$ Imagine if these three examples concerned animals other than fishes ${ }^{5}$ - how would the public react? It is questionable whether people would go on a trip where they closely interact with endangered mammals, for example, and then directly afterwards try their flavour by eating them. Probably, most people would feel (at least) uncomfortable - but would they do so in the case of fishes? ${ }^{6}$ In view of the EU campaign, to which 'love story' is the EU Commission referring? Looking at the common practices of industrial fishing, farming and slaughtering of fishes, the 'relation' between humans and fishes is based on extreme exploitation, rather than on love and compassion. Thus, calling it a 'love story' appears inappropriate - just as it does when gambling with the lives of fishes for artistic reasons to demonstrate how "people wrestle with their conscience". ${ }^{7}$ Would people have also blended other animals like mice or small birds, for example, as some of the visitors did indeed with several goldfish individuals?

Fish - these four letters stand for an enormous number of trillions of animals described in 33,900 different species of 567 different families, living either in marine or fresh waters, or both, ${ }^{8}$ and representing around " $60 \%$ of all the known species on Earth with backbones". 9 As suggested by Jonathan Balcombe (2016) in his book What a Fish Knows, to recognize that "these animals are individuals with personalities and relationships", ${ }^{10}$ the use of the plural form of 'fishes' seems much more adequate than the commonly used singular 'fish'. Up to the present day we only know little about their inner life - and indeed it took a long time, not only for science but also for policy and not least the public, to ask the question whether fishes are capable of experiencing pain, fear and suffering (not to mention positive mental states). ${ }^{11}$ And even now there are voices denying that fishes feel pain. For example, in 2016 Brian Key published an article stating that due to the lack of a human-like neocortex ${ }^{12}$ and the neuroanatomical features of a fish brain, they are not capable of conscious feeling of pain. ${ }^{13}$ This argument is not new, ${ }^{14}$ but (luckily) evoked numerous commentaries of fish experts who have spoken out for the fishes and negated Key's argumentation. ${ }^{15}$ Victoria Braithwaite and Lynne Sneddon have been among those experts, and they were two of the first showing that fishes do not simply react to aversive stimuli with reflexes, but that they indeed experience pain and fear. ${ }^{16}$ With their work they made, among others, a significant contribution towards a better

\footnotetext{
${ }^{1} \mathrm{http}: / /$ tuna-tour.com/en/estas-preparado/, 25.05.2018

${ }^{2}$ Ibid.

${ }^{3}$ https://ec.europa.eu/fisheries/inseparable/en, 25.05.2018

${ }^{4}$ BRAITHWAITE, V. Do fish feel pain? (Oxford 2010) 114

5 Admittedly, in this context 'other animals' refers only to terrestrial vertebrates like mammals and birds but does not take into account invertebrates.

${ }^{6}$ The Atlantic blue fin tuna is listed as engendered species. See: http://www.iucnredlist.org/details/21860/0, 25.05.2018

${ }^{7}$ BRAITHWAITE, V. Do fish feel pain? (Oxford 2010) 114

8 According to FishBase database, http://www.fishbase.de/Report/FishesUsedByHumans.php, 25.05.2018/ Fishes can mainly be categorized into three major groups: Agnatha (hagfish and lampreys), Chondrichthyes (sharks, rays and sturgeon), and Actinopterygii (ray-finned bony fishes) (see: EFSA (2009) Scientific Opinion on general approach to fish welfare and to the concept of sentience in fish. p. 5). Within the Actinopterygii is included the teleost ('real' bony fishes) as the biggest group of modern fishes today - including, inter alia, most 'farmed' fish species such as salmon, bass, tuna, eel, carp but also herring or goldfish [see e.g. BALCOMBE, J., What a fish knows - The inner lives of our underwater cousins (New York 2016) 11]

${ }^{9}$ BALCOMBE, J., What a fish knows - The inner lives of our underwater cousins (New York 2016) 11

${ }^{10}$ Ibid. 6

${ }^{11}$ Until the end of the $20^{\text {th }}$ century, nearly no research had been done on fish pain perception, not even asking the "straightforward question about whether fish[es] had the necessary gross anatomy to detect pain" [BRAITHWAITE, V. Do fish feel pain? (Oxford 2010) 48]

12 The neocortex in mammalian brains "plays a key role in subjective experience of pain in humans", EFSA (2009) Scientific Opinion on general approach to fish welfare and to the concept of sentience in fish, 13

${ }^{13} \mathrm{KEY}$, B., Why fish do not feel pain. Animal Sentience 3/1 (2016) 1-17. Online available:

https://animalstudiesrepository.org/animsent/vol1/iss3/1/ [last access: 25.05.2018]

${ }^{14}$ E.g. ROSE, J.D., The neurobehavioral nature of fishes and the question of awareness and pain. Rev. Fish. Sci. 10. p. 1-38. Online available: https://www.tandfonline.com/doi/abs/10.1080/20026491051668 [last access: 25.05.2018]

${ }^{15}$ See: https://animalstudiesrepository.org/animsent/vol1/iss3/1/, 25.05.2018

${ }^{16}$ SNEDDON, L.U., BRAITHWAITE, V. AND GENTLE, M.J., Novel object test: examining nociception and fear in the rainbow
} 
understanding of the inner lives of fishes, as will be seen in the following.

Pain, which is defined as "aversive sensation and feeling associated with actual or potential tissue damage" ${ }^{17}$ can be distinguished in two different phases - the unconscious phase called nociception, and the conscious phase. ${ }^{18}$ Whereas nociception simply describes the automatic reflex response of the nervous system to a negative, noxious stimulus (such as temperature, mechanical pressure or chemicals), the second phase implies that the pain signal is further conveyed via the spinal cord to the brain, where it is transposed into the emotional feeling and experience of pain. ${ }^{19}$ In essence, the individual concerned becomes cognitively aware of the pain, which can then obviously cause suffering. Fishes not only possess numerous nociceptors, which are necessary to detect negative stimuli and are distributed all over their body (especially around critical parts like eyes, mouths or fins), they also have the functional pathways transmitting the pain signal from the nociceptor to the brain. As in humans, fishes also have A-delta and C-delta nerve fibres for the important pain stimuli transfer to the brain. ${ }^{20}$ Finally the question of whether fishes have the anatomical features for pain detection could be answered with yes, inter alia, by Braithwaite and Sneddon in 2003. ${ }^{21}$ They also demonstrated in experiments with rainbow trout that fishes, when treated with aversive noxious stimuli like acidic vinegar or bee venom injected into their lips, showed: (1) physiological reactions like an accelerated breathing rate (i.e. gill cover movement/ventilation much quicker than in normal conditions) and loss of appetite, which are also typical reactions in mammals (including humans) and birds; ${ }^{22}$ (2) changes in their behaviour due to the painful stimulation, for example those fishes treated with the chemical substances rubbed their inflamed lip region against the wall or ground of the tank indicating that they tried to get rid of this painful stimulus - just like we do when we start to scratch itching bee stings, for example; and (3) an "impaired cognitive ability [of the fishes] caused by noxious stimulation," ${ }^{23}$ in essence that those fishes treated with the chemical substances were so distracted by pain they were not able to show normal avoidance and fear behaviour when exposed to novel objects. Interestingly, after the treated fishes received painkiller (morphine) they showed again the same normal avoidance behaviour as their 'untreated' companions of the control group. ${ }^{24}$ This led to the conclusion that the fishes do indeed perceive and feel pain. Due to their behavioural responses, which differed depending on whether the fishes were under pain or received painkiller, they "must be cognitively aware and experiencing the negative experiences associated with pain." ${ }^{25}$ Consequently, since fishes feel pain consciously, they should be capable of suffering. Suffering, as well as any other feeling, is always a subjective, personal experience and without doubt, not only for fishes, difficult to describe scientifically, likewise for sentience and consciousness. However, there is more and more evidence from the scientific side that fishes do also have these capacities. Even though they lack a human-like neocortex, apparently other parts of the fish brain seem to be responsible for processing emotions and consciousness. ${ }^{26}$ Beside these, some remarkable observations have been made.

Contrary to the popular misconception of the 'three-second memory', fishes have an excellent memory of their spatial environment. They use landmarks for orientation, and remember these when planning different escape routes or when finding their way out of a maze. ${ }^{27}$ They not only recognize the different individuals in their shoal, but also remember their hierarchical status in the group. ${ }^{28}$ As experiments showed, fishes who had observed fights between different fishes were able to later "memoriz[e] the identity of the different individuals and $\operatorname{lin}[\mathrm{k}]$ this with information on their previous fighting abilities". ${ }^{29}$ In essence, when in a later encounter the 'observer fishes' had to decide to prefer the 'winner' or 'loser' fishes to fight with, they took the weaker ones. As stated by Victoria Braithwaite, creating such relations between different individuals may sound easy, but, for example, four-year-old children still find this very

trout. J Pain 4/8 (2003a) 431-440. Online available: https://www.ncbi.nlm.nih.gov/pubmed/14622663 [last access: 25.05.2018]

${ }^{17}$ EFSA, General approach to fish welfare and to the concept of sentience in fish (2009) 12

${ }^{18}$ BRAITHWAITE, V. Do fish feel pain? (Oxford 2010) 44

${ }^{19}$ Ibid. $44-45$

${ }^{20}$ Ibid. 51-52 / NB: At least, these A-delta and C-fibres are found in teleost fish species; for other groups like sharks and rays less is known due to lack of research, see: SNEDDON, L., Pain in aquatic animals. J. Exp. Biol. 218 (2015) 967-976. Online available: http://jeb.biologists.org/content/218/7/967 [last access: 25.05.2018]

${ }^{21}$ SNEDDON, L.U., BRAITHWAITE, V. \& GENTLE, M.J., Do fishes have nociceptors? Evidence for the evolution of a vertebrate sensory system. Proceedings of the Royal Society of London Series B - Biological Sciences 270/1520 (2003b) 1115-1121. Online available: https://www.ncbi.nlm.nih.gov/pmc/articles/PMC1691351/ [last access: 25.05.2018]

${ }^{22}$ BRAITHWAITE, V. Do fish feel pain? (Oxford 2010) 46-74

${ }^{23}$ Ibid. 74

${ }^{24}$ Ibid. 69

${ }^{25}$ Ibid. 69

${ }^{26}$ EFSA, General approach to fish welfare and to the concept of sentience in fish (2009) 18-19; BRAITHWAITE, V. Do fish feel pain? (Oxford 2010) 99-102

${ }^{27}$ BRAITHWAITE, V. Do fish feel pain? (Oxford 2010) 83-90

${ }^{28}$ Ibid. $90-95$

${ }^{29}$ Ibid. 93

74 Derecho Animal. Forum of Animal Law Studies, vol. 10/2 
difficult. ${ }^{30}$ Another, probably the most famous, example strongly supporting that fishes are conscious is the interspecific cooperation of fishes observed between grouper and moray eels in reefs of the Red Sea. ${ }^{31}$ These two species hunt very differently - grouper are big reef predators and thus cannot follow their prey if they escape into the holes and crevices of the reef, whereas moray eels are perfectly adapted to hunt inside the 'reef maze' due to their snake-like body shape. By building an alliance, groupers and moray eels found a way to increase their hunting success. Most astonishing is that the grouper calls the moray eel when a prey fish has escaped into a reef hole. That is to say that grouper and moray eels do not start hunting together, but when the hunt appears desperate for the grouper, he or she searches for a moray eel and indicates by a typical head shaking pattern, not only to follow, but also where the prey is hidden. If the moray eel is hungry, he or she probably follows the grouper and tries to find the prey fish. With a fifty-fifty chance, either the moray eel catches the prey or the grouper who awaits the prey outside the reef maze gets a second chance. This example is extraordinary as the grouper and moray eels have invented an interspecific 'sign language' that both are able to understand, and it clearly shows that fishes are able to communicate "their intentions to one another to induce cooperative behaviour". ${ }^{32}$ Another example of the complex cognitive and social skills of fishes has been described only recently: the capacity of direct reciprocity ${ }^{33}$ in coordinated foraging and vigilance behaviour, observed in coral reef rabbitfishes. ${ }^{34}$ In pairs, one fish feeds on reef substratum while the other is checking the surrounding area for possible predators. They then turn so that the other fish can eat undisturbed, and so on. This "reciprocity or 'reciprocal altruism' which involves a costly action beneficial for another individual" ${ }^{35}$ assumes highly cognitive and social skills in these fishes, since reciprocity not only requires "the recognition of individual partners, [but also] the capacity to recall their previous action, [and] the ability to make intentional investments under the expectation that it will entail a future reward". 36

In conclusion, all the observations described above (and many more) clearly give strong evidence that fishes are conscious, sentient beings - and indeed since 2009 they are recognized as such by the EU in article 13 TFEU. Even though "full regard to the welfare requirements of animals" must be paid when "formulating and implementing the Union's (...) fisheries (...) policies", ${ }^{37}$ reality paints a different picture. Under protection and welfare aspects of secondary EU legislation, the fishes are either only included on a very basic general level, ${ }^{38}$ or not considered at all. ${ }^{39}$ Despite the fact that science cannot fully explain every process involved in the emotional experience of fishes, "the precautionary principle dictates that we should give the benefit of the doubts to fish[es]", ${ }^{40}$ especially when considering how we mainly 'interact' with them: they are used and killed in unimaginable numbers of up to several trillions, for example by "crushing, decompression, asphyxiation or exsanguination" ${ }^{41}$ It is about time to overcome "the erroneous view that fish[es] have little awareness or cognitive ability" ${ }^{42}$ and to finally grant them the protection they deserve as 'sentient beings' on the legislative level, but also in fisheries and aquaculture practices, policies and not least in our daily behaviour. Are you ready for this?

\footnotetext{
${ }^{30}$ Ibid. 92

${ }^{31}$ Ibid. 106-111

${ }^{32}$ Ibid. 108. Seemingly, this successful cooperation went around among other groupers and moray eels who watched and copied it through cultural transmission.

${ }^{33}$ Reciprocity generally refers to complex cognitive abilities including "the recognition of individual partners, the capacity to recall their previous action, or the ability to make intentional investments under the expectation that it will entail a future reward", see: BRANDL, S.J. \& BELLWOOD, D.R., Coordinated vigilance provides evidence for direct reciprocity in coral reef fishes. Sci. Rep. 5 (2015) 1. Online available: https://www.nature.com/articles/srep14556 [last access: 25.05.2018]

${ }^{34}$ BRANDL, S.J. \& BELLWOOD, D.R., Coordinated vigilance provides evidence for direct reciprocity in coral reef fishes. Sci. Rep. 5, 1-13. Online available: https://www.nature.com/articles/srep14556 [last access: 25.05.2018]

35 Ibid. 1

${ }^{36}$ Ibid. 1

${ }^{37}$ Article 13 of the Treaty on the Functioning on the European Union

${ }^{38}$ E.g. Council Directive 98/58/EC, Council Regulation (EC) No 1/2005, Council Regulation (EC) 1099/2009

${ }^{39}$ E.g. Council Regulation (EC) No 1005/2008

40 BALCOMBE, J., Cognitive evidence of fish sentience. Commentary on Key on Fish Pain. (2016) 1. Online available: https://animalstudiesrepository.org/animsent/vol1/iss3/2/ [last access: 25.05.2018]

${ }^{41}$ Ibid. 2

42 EFSA, Scientific Report of the Scientific Panel on Animal Health and Welfare on a request from the Commission related to the welfare of animals during transport. The EFSA Journal 44 (2004) 10
} 


\section{REFERENCES}

\section{Books, Articles and reports}

- BALCOMBE, J., What a fish knows - The inner lives of our underwater cousins (New York 2016)

- BALCOMBE, J., Cognitive evidence of fish sentience. Commentary on Key on Fish Pain (2016) 1. Online available: https://animalstudiesrepository.org/animsent/vol1/iss3/2/ [last access: 25.05.2018]

- BRAITHEWAITE, V., Do fish feel pain? (Oxford 2010)

- BRANDL, S.J. \& BELLWOOD, D.R., Coordinated vigilance provides evidence for direct reciprocity in coral reef fishes. Sci. Rep. 5. (2015) 1-13. Online available:

https://www.nature.com/articles/srep14556 [last access: 25.05.2018]

- EFSA, Scientific Report of the Scientific Panel on Animal Health and Welfare on a request from the Commission related to the welfare of animals during transport. The EFSA Journal 44 (2004) 1-36

- EFSA (2009) Scientific Opinion of the panel on animal health and welfare on a request from European Commission on general approach to fish welfare and to the concept of sentience in fish. The EFSA Journal 954 (2009) 1-26

- KEY, B., Why fish do not feel pain. Animal Sentience 3/1 (2016) 1-33. Online available: https://animalstudiesrepository.org/animsent/vol1/iss3/1/ [last access: 25.05.2018]

- ROSE, J.D., The neurobehavioral nature of fishes and the question of awareness and pain. Rev. Fish. Sci. 10 (2002) 1-38. Online available:

https://www.tandfonline.com/doi/abs/10.1080/20026491051668 [last access: 25.05.2018]

- SNEDDON, L.U., Pain in aquatic animals. J. Exp. Biol. 218 (2015) 967-976. Online available: http://jeb.biologists.org/content/218/7/967 [last access: 25.05.2018]

- SNEDDON, L.U., BRAITHWAITE, V. AND GENTLE, M.J., Novel object test: examining nociception and fear in the rainbow trout. J Pain 4/8 (2003a) 431-440. Online available: https://www.ncbi.nlm.nih.gov/pubmed/14622663 [last access: 25.05.2018]

- SNEDDON, L.U., BRAITHWAITE, V. \& GENTLE, M.J., Do fishes have nociceptors? Evidence for the evolution of a vertebrate sensory system. Proceedings of the Royal Society of London Series B Biological Sciences 270/1520 (2003b) 1115-1121. Online available:

https://www.ncbi.nlm.nih.gov/pmc/articles/PMC1691351/ [last access: 25.05.2018]

\section{Legal references}

\section{Primary EU Legislation:}

- Consolidated version of the treaty on the Functioning of the European Union (2012/C 326/47). Online available:

http://eur-lex.europa.eu/legal-content/EN/TXT/PDF/?uri=CELEX:12012E/TXT\&from=DE

$\underline{\text { Secondary EU Legislation: }}$

- COUNCIL REGULATION (EC) No 1/2005 of 22 December 2004 on the protection of animals during transport and related operations and amending Directives 64/432/EEC and 93/119/EC and Regualtion (EC) No 1255/97.

- Online available: http://eur-lex.europa.eu/legal-content/en/ALL/?uri=CELEX:32005R0001

- COUNCIL REGULATION (EC) No 1005/2008 of 29 September 2008 establishing a Community system to prevent, deter and eliminate illegal, unreported and unregulated fishing, amending Regulations (EEC) No 2847/93, (EC) No 1936/2001 and (EC) No 601/2004 and repealing Regulations (EC) No 1093/94 and (EC) No 1447/1999.

- Online available: http://eur-lex.europa.eu/legal-content/EN/TXT/PDF/?uri=CELEX:02008R100520110309\&from=EN

- COUNCIL REGULATION (EC) No 1099/2009 of 24 September 2009 on the protection of animals at the time of killing.

- Online available: http://eur-lex.europa.eu/legal-content/EN/ALL/?uri=CELEX:32009R1099

- COUNCIL DIRECTIVE 98/58/EC of 20 July 1998 concerning the protection of animals kept for farming purposes.

- Online available: http://eur-lex.europa.eu/legal-content/EN/TXT/?uri=celex:31998L0058 
Internet Sources

[last date of consultation: 25.05.2018]

- https://animalstudiesrepository.org/animsent/vol1/iss3/1/ (commentaries on Key article on fish pain)

- https://ec.europa.eu/fisheries/inseparable/en

- http://www.fishbase.de/Report/FishesUsedByHumans.php

- http://www.iucnredlist.org/details/21860/0

- http://tuna-tour.com/en/estas-preparado/ 